Supplement of Biogeosciences, 11, 3095-3106, 2014

http://www.biogeosciences.net/11/3095/2014/

doi:10.5194/bg-11-3095-2014-supplement

(C) Author(s) 2014. CC Attribution 3.0 License.

(c) (i)

Supplement of

\title{
The net exchange of methane with high Arctic landscapes during the sum- mer growing season
}

\section{A. Emmerton et al.}

Correspondence to: C. A. Emmerton (emmerton@ualberta.ca) 


\section{Supplement}

\section{TABLES}

Table S1 Meteorological and soil measurements collected by sensors mounted on the eddy covariance towers at the desert and wetland sites.

\begin{tabular}{|c|c|}
\hline \multicolumn{2}{|l|}{ Meteorological measurements } \\
\hline Air temperature & HMP45C212 temp./humidity probes inside radiation shields \\
\hline Air pressure & Licor LI-7500 $\mathrm{CO}_{2} / \mathrm{H}_{2} \mathrm{O}$ gas analyzer \\
\hline Wind speed and direction & Campbell Scientific CSAT3 sonic anemometers \\
\hline Net, photosynthetically active radiation & Kipp \& Zonen net and PAR radiometers \\
\hline Precipitation & TE525 Tipping Bucket rain gauge \\
\hline \multicolumn{2}{|l|}{ Soil measurements } \\
\hline Soil temperature & CS107B soil temperature probes \\
\hline Soil moisture & CS616-L soil water content reflectometers \\
\hline Soil heat flux at $5 \mathrm{~cm}$ depth & CSHFT3 soil heat flux plates \\
\hline
\end{tabular}


Table S2 Spearman rank correlation matrix of daily mean environmental parameters and mean $\mathrm{CH}_{4}$ fluxes from desert chambers (A.) and wetland chambers (B.) during the 2008-12 growing seasons. Bold indicates statistical significance at $\alpha=0.05$.

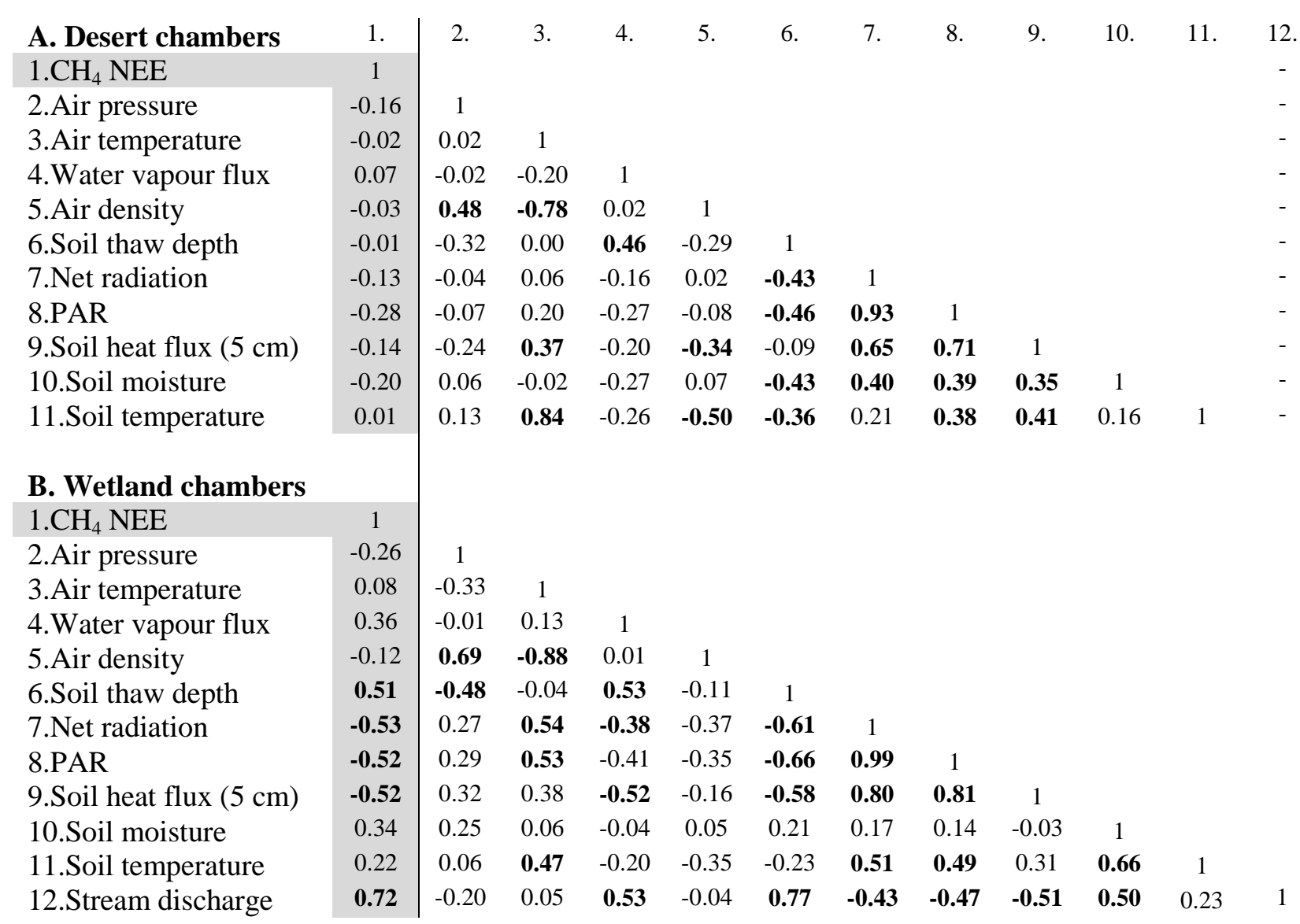


Table S3 Spearman rank correlation matrix of environmental factors and mean $\mathrm{EC} \mathrm{CH}_{4}$ fluxes from wetland LI-7700 measurements during the 2012 growing season. Bold indicates statistical significance at $\alpha=0.05$.

\begin{tabular}{|c|c|c|c|c|c|c|c|c|c|c|c|c|c|c|c|}
\hline & & 1. & 2. & 3. & 4. & 5. & 6. & 7. & 8. & 9. & 10. & 11. & 12. & 13. & 14. \\
\hline \multirow{7}{*}{ 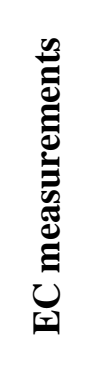 } & 1. $\mathrm{CH}_{4} \mathrm{NEE}$ & 1 & & & & & & & & & & & & & \\
\hline & 2. Momentum flux & 0.35 & 1 & & & & & & & & & & & & \\
\hline & 3. Sensible heat flux & 0.09 & 0.32 & 1 & & & & & & & & & & & \\
\hline & 4. Latent energy flux & 0.22 & 0.40 & 0.59 & 1 & & & & & & & & & & \\
\hline & 5. $\mathrm{CO}_{2}$ flux & -0.71 & -0.01 & 0.19 & 0.03 & 1 & & & & & & & & & \\
\hline & 6. Water vapour flux & 0.21 & 0.39 & 0.59 & 1.00 & 0.03 & 1 & & & & & & & & \\
\hline & 7. Friction velocity & 0.36 & 0.99 & 0.30 & 0.39 & 0.00 & 0.39 & 1 & & & & & & & \\
\hline \multirow{7}{*}{ 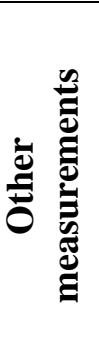 } & 8. Net radiation & -0.38 & 0.20 & 0.73 & 0.49 & 0.60 & 0.49 & 0.18 & 1 & & & & & & \\
\hline & 9. PAR & 0.00 & 0.26 & 0.79 & 0.74 & 0.14 & 0.74 & 0.24 & 0.80 & 1 & & & & & \\
\hline & 10. Soil heat flux $(5 \mathrm{~cm})$ & 0.03 & -0.11 & 0.11 & 0.25 & -0.04 & 0.25 & -0.15 & 0.29 & $\mathbf{0 . 3 3}$ & 1 & & & & \\
\hline & 11. Soil moisture & 0.09 & 0.46 & 0.37 & 0.38 & 0.31 & 0.37 & 0.52 & 0.26 & 0.21 & -0.48 & 1 & & & \\
\hline & 12. Soil temperature & 0.65 & 0.18 & 0.15 & 0.53 & -0.58 & 0.53 & 0.17 & -0.22 & 0.28 & 0.09 & 0.12 & 1 & & \\
\hline & 13. Air pressure & -0.36 & -0.19 & 0.35 & 0.05 & 0.39 & 0.06 & -0.22 & 0.54 & 0.44 & 0.47 & -0.26 & -0.21 & 1 & \\
\hline & 14. Air temperature & 0.49 & 0.25 & 0.18 & 0.70 & -0.43 & 0.70 & 0.27 & -0.03 & 0.45 & 0.17 & 0.29 & 0.82 & -0.27 & 1 \\
\hline
\end{tabular}


Table S4 Summary table of site mean $\mathrm{CH}_{4}$ fluxes $\left(\mathrm{F}_{\mathrm{CH}}\right)$ measured in high-, low- and subarctic tundra (as defined by $A M A P, 1998$ ) for some portion of the northern growing season (MayOctober). Fluxes organized by chamber and eddy covariance measurements and by terrestrial sites predominantly emitting or consuming $\mathrm{CH}_{4}$. All fluxes in $\mathrm{mg} \mathrm{CH}_{4} \mathrm{~m}^{-2} \mathrm{~d}^{-1}$.

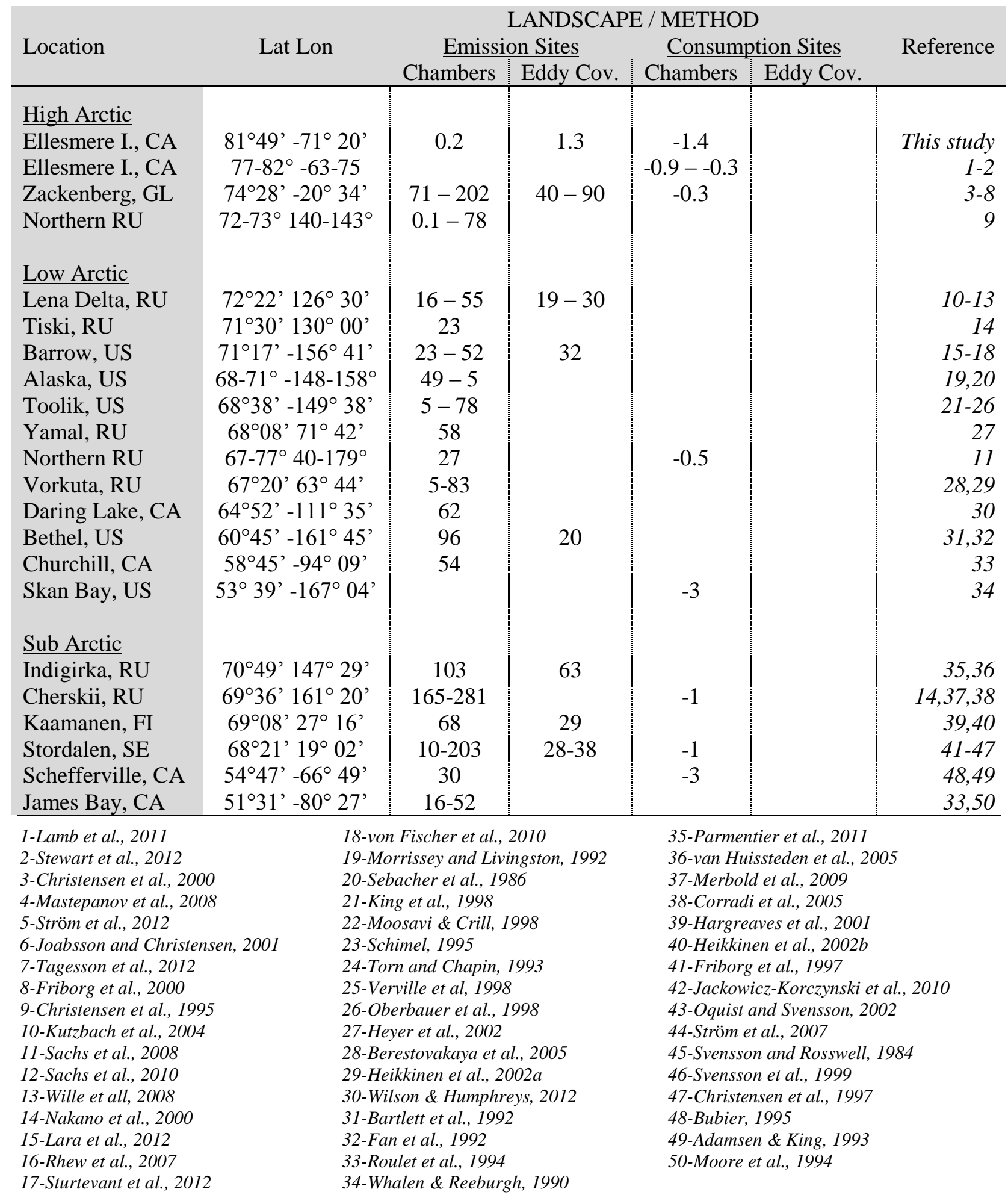


Table S5 Concentrations ( $\pm 1 \mathrm{SD}$ ) of several chemicals downstream through the Skeleton Creek wetland complex. All chemicals are reported in $\mu \mathrm{mol} \mathrm{L}^{-1}$.

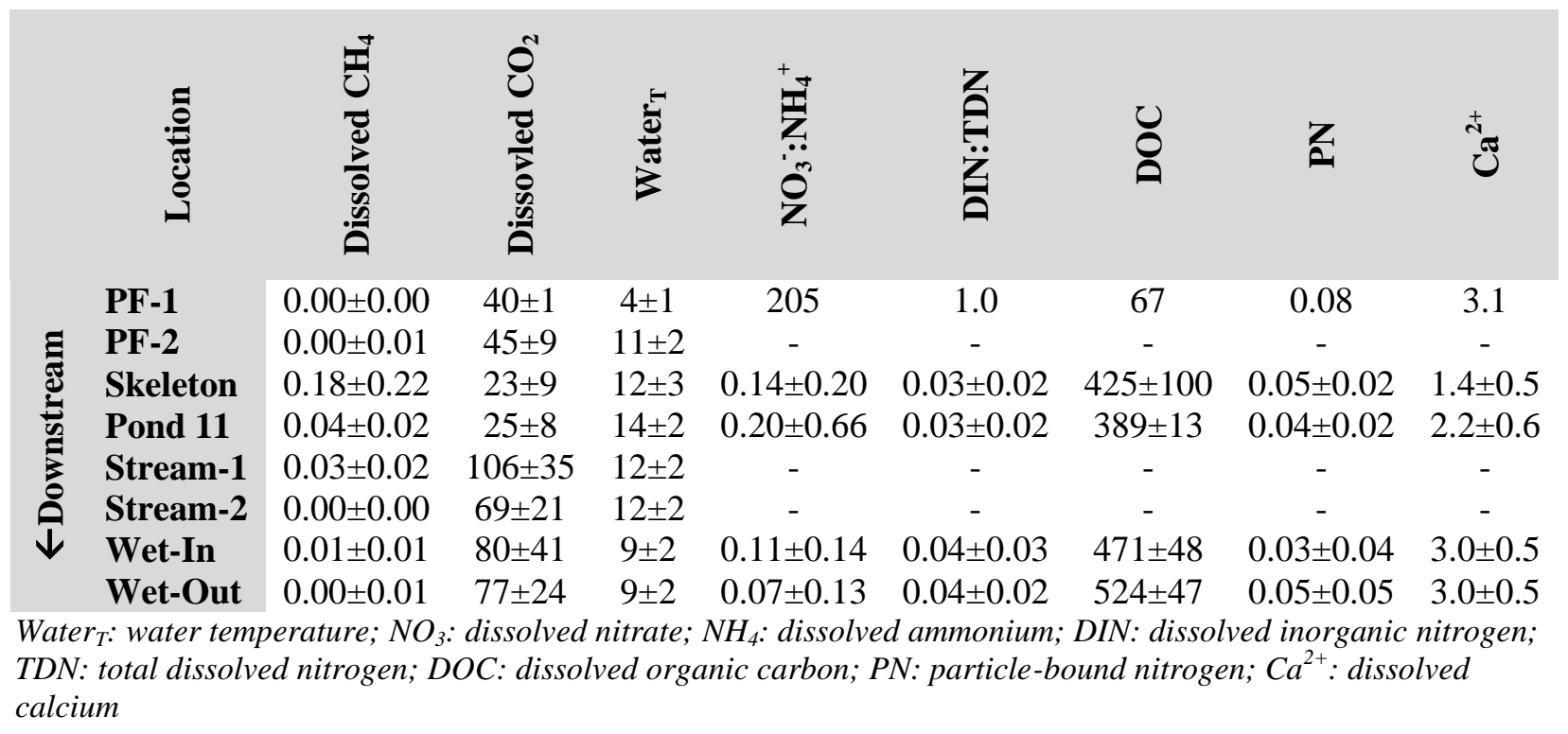




\section{FIGURES}

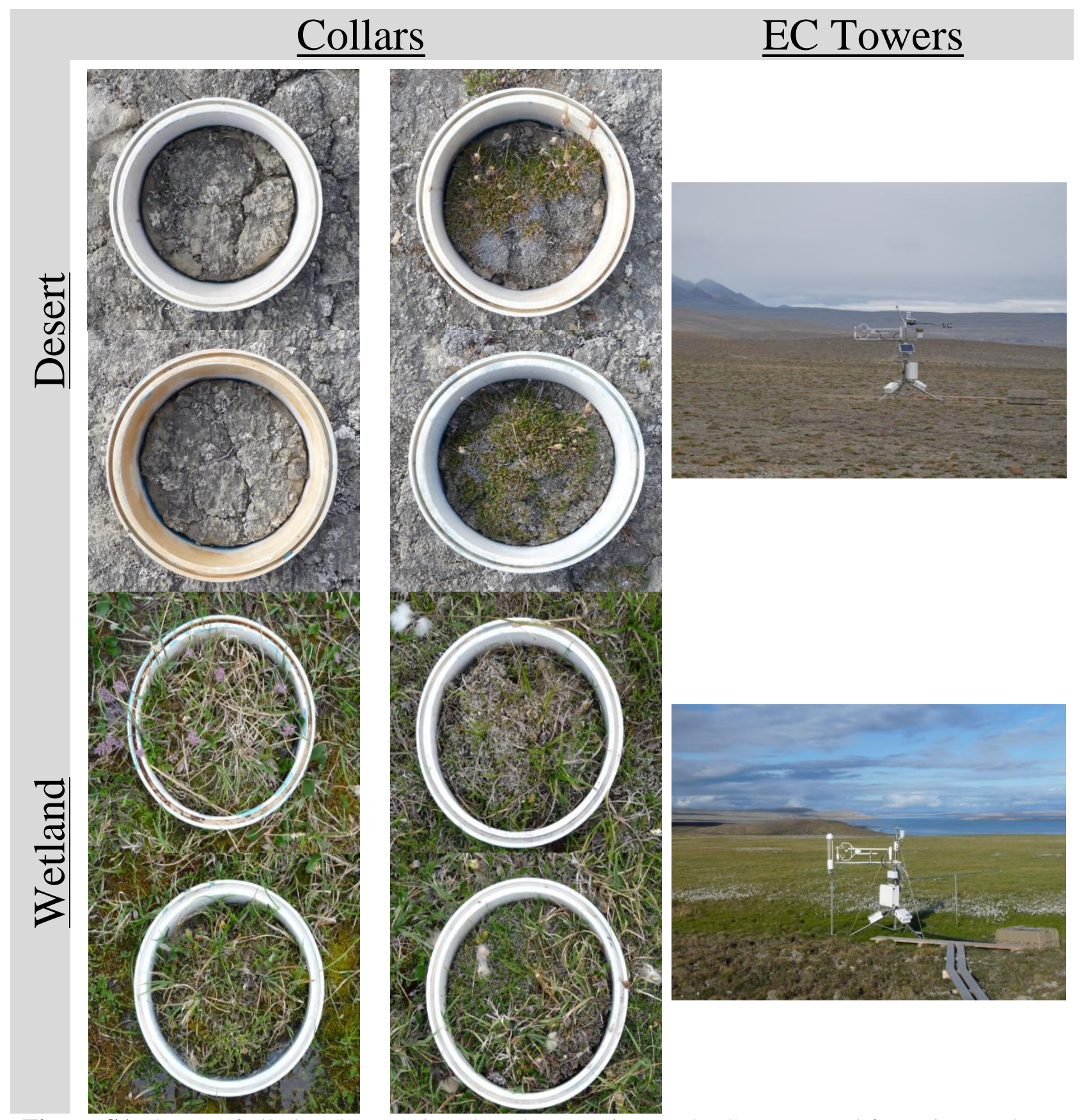

Figure S1 Photos of all chambers and enclosed vegetation, and EC towers and footprints at the desert and wetland sites. Photos taken during the growing season (photos by C. Emmerton). 


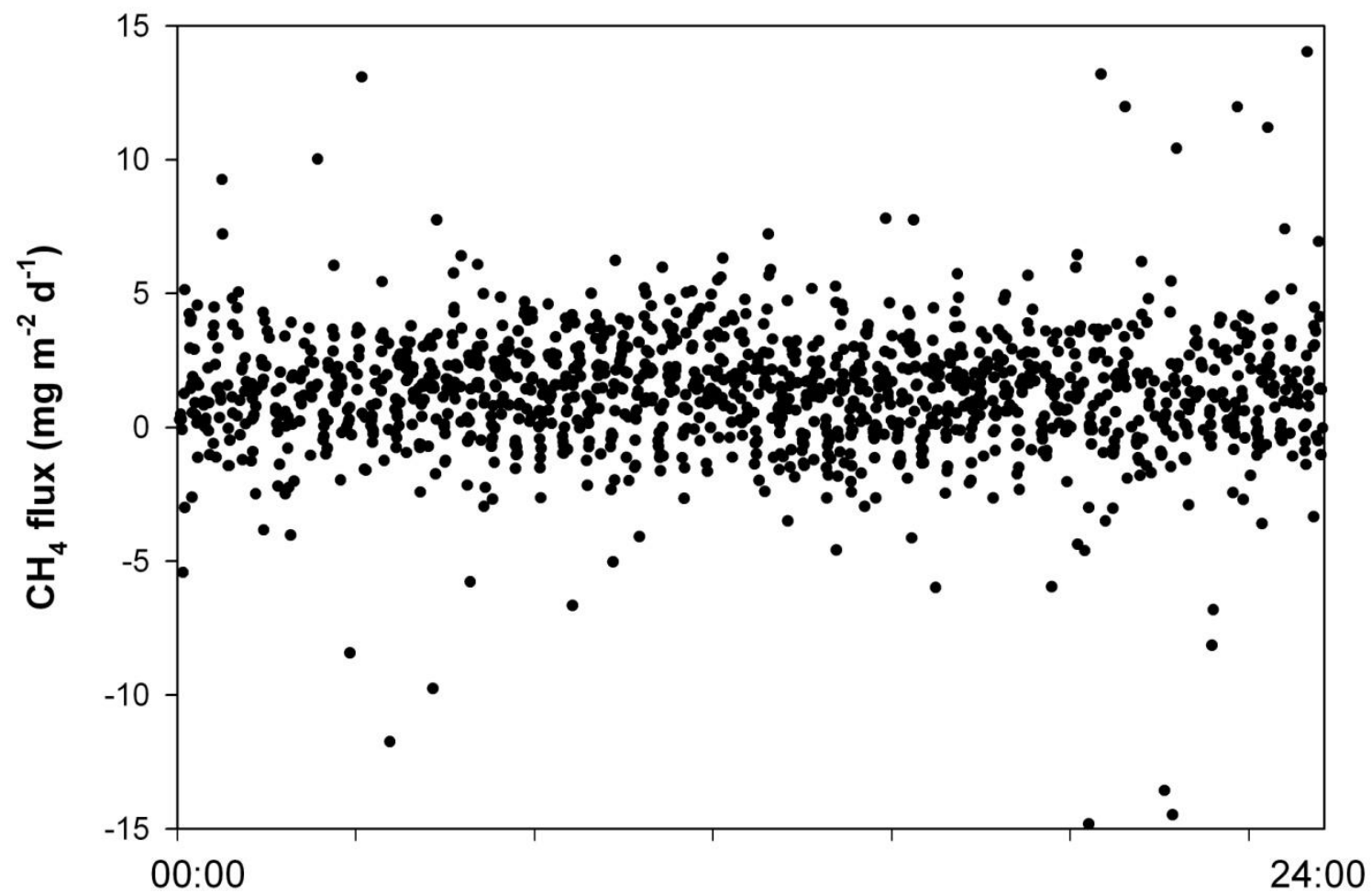

Figure S2 Diurnal organization of all half-hourly $\mathrm{CH}_{4}$ fluxes for the 2012 growing season at the wetland as measured by the EC tower. 

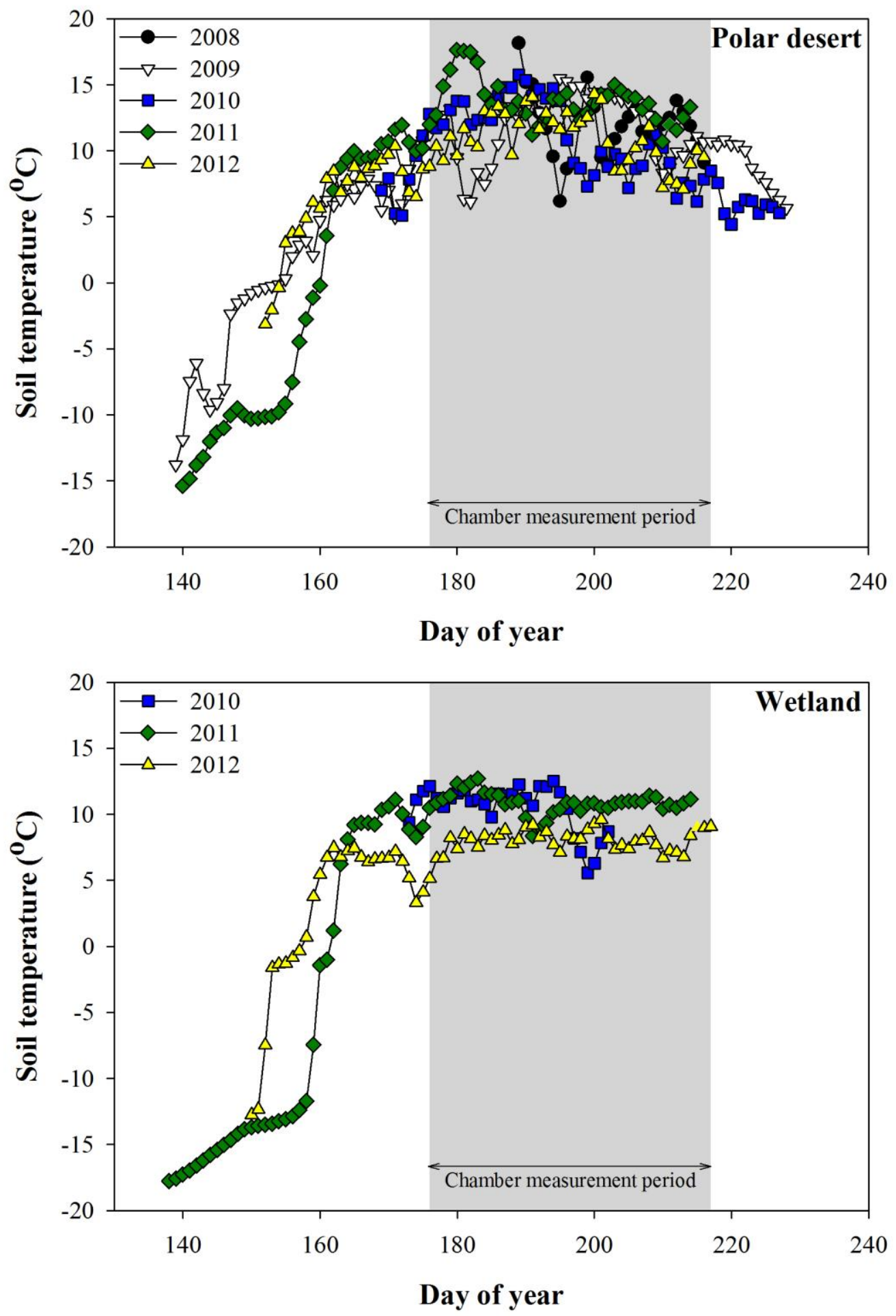

Figure S3 Soil temperatures at $5 \mathrm{~cm}$ depth during the growing seasons of 2008 to 2012 at the desert (upper) and wetland (lower) eddy covariance flux towers. 

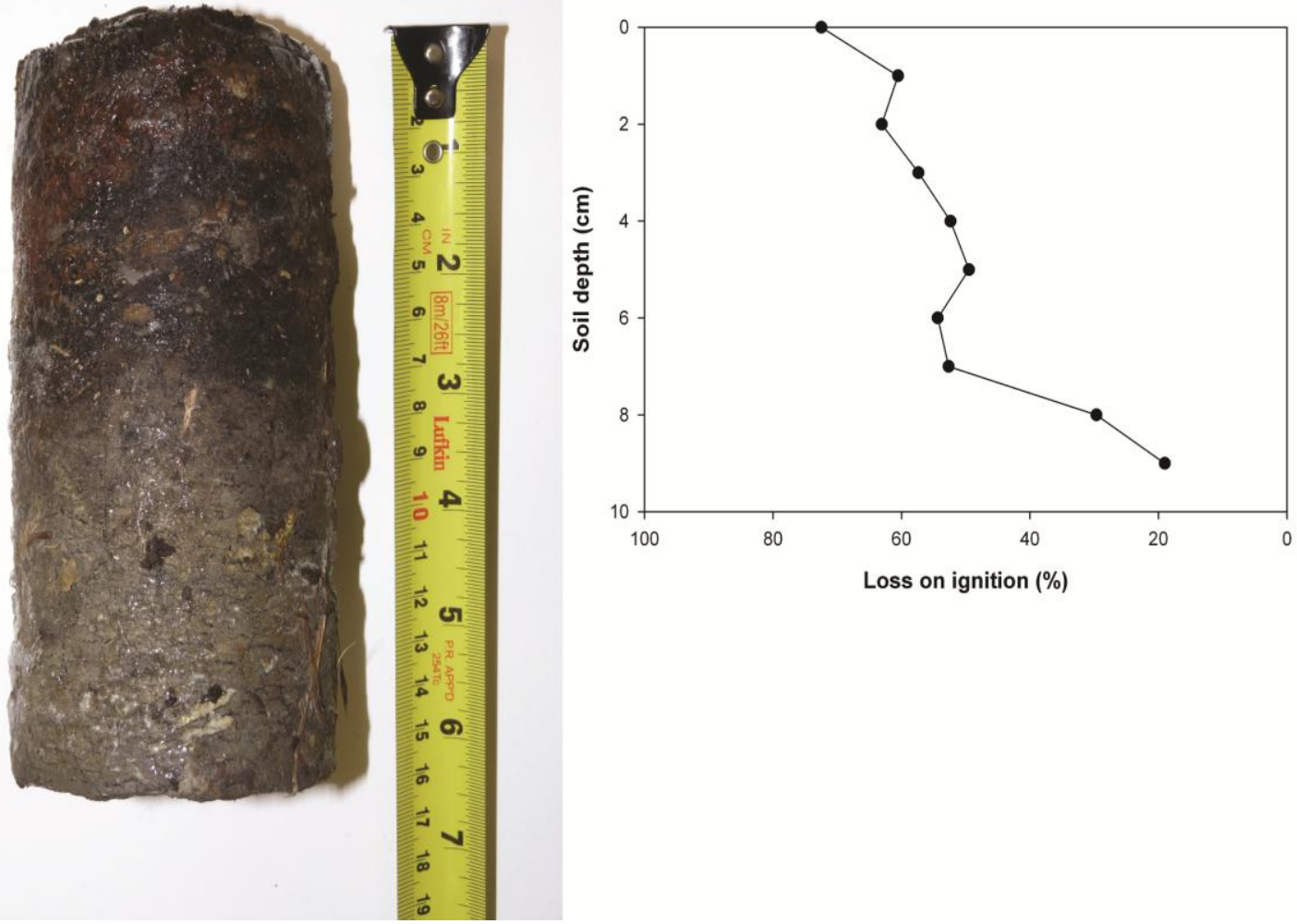

Figure S4 Photograph of a soil core extracted from the approximate middle of the wetland in May 2011 during frozen conditions (left panel). Graph of loss of ignition values $\left(550^{\circ} \mathrm{C}\right)$ by depth for $0.5 \mathrm{~cm}$ portions of the wetland core (right panel) (photo by C. Emmerton). 


\section{References}

Adamsen, A.P.S., and G.M. King (1993), Methane Consumption in Temperate and Sub-Arctic Forest Soils - Rates, Vertical Zonation, and Responses to Water and Nitrogen, Applied and Environmental Microbiology, 59, 485-490.

Bartlett, K.B., P.M. Crill, R.L. Sass, R.C. Harriss, and N.B. Dise (1992), Methane Emissions from Tundra Environments in the Yukon-Kuskokwim Delta, Alaska, Journal of Geophysical Research-Atmospheres, 97, 16645-16660.

Berestovskaya, Y.Y., I.I. Rusanov, L.V. Vasil'eva, and N.V. Pimenov (2005), The processes of methane production and oxidation in the soils of the Russian Arctic tundra. Microbiology, 74, 221-229.

Bubier, J.L. (1995), The Relationship of Vegetation to Methane Emission and Hydrochemical Gradients in Northern Peatlands, Journal of Ecology, 83, 403-420.

Christensen, T.R., S. Jonasson, T.V. Callaghan, and M. Havstrom (1995), Spatial Variation in High-Latitude Methane Flux Along a Transect across Siberian and European Tundra Environments, Journal of Geophysical Research-Atmospheres, 100, 21035-21045.

Christensen, T.R., A. Michelsen, S. Jonasson, and I.K. Schmidt (1997), Carbon dioxide and methane exchange of a subarctic heath in response to climate change related environmental manipulations, Oikos, 79, 34-44.

Christensen, T.R., T. Friborg, M. Sommerkorn, J. Kaplan, L. Illeris, H. Soegaard, C. Nordstroem, and S. Jonasson (2000), Trace gas exchange in a high-arctic valley 1. Variations in $\mathrm{CO} 2$ and $\mathrm{CH} 4$ flux between tundra vegetation types, Global Biogeochemical Cycles, 14, 701-713.

Corradi, C., O. Kolle, K. Walter, S.A. Zimov, and E.D. Schulze (2005), Carbon dioxide and methane exchange of a north-east Siberian tussock tundra, Global Change Biology, 11, 19101925.

Fan, S.M., S.C. Wofsy, P.S. Bakwin, D.J. Jacob, S.M. Anderson, P.L. Kebabian, J.B. McManus, C.E. Kolb, and D.R. Fitzjarrald (1992), Micrometeorological Measurements of Ch4 and Co2 Exchange between the Atmosphere and Sub-Arctic Tundra, Journal of Geophysical ResearchAtmospheres, 97, 16627-16643.

Friborg, T., T.R. Christensen, and H. Sogaard (1997), Rapid response of greenhouse gas emission to early spring thaw in a subarctic mire as shown by micrometeorological techniques, Geophysical Research Letters, 24, 3061-3064.

Friborg, T., T.R. Christensen, B.U. Hansen, C. Nordstroem, and H. Soegaard (2000), Trace gas exchange in a high-arctic valley 2. Landscape $\mathrm{CH} 4$ fluxes measured and modeled using eddy correlation data, Global Biogeochemical Cycles, 14, 715-723.

Hargreaves, K.J., D. Fowler, C.E.R. Pitcairn, and M. Aurela (2001), Annual methane emission from Finnish mires estimated from eddy covariance campaign measurements, Theoretical and Applied Climatology, 70, 203-213.

Heikkinen, J.E.P., V. Elsakov, and P.J. Martikainen (2002a), Carbon dioxide and methane dynamics and annual carbon balance in tundra wetland in NE Europe, Russia, Global Biogeochemical Cycles, 16.

Heikkinen, J.E.P., M. Maljanen, M. Aurela, K.J. Hargreaves, and P.J. Martikainen (2002b), Carbon dioxide and methane dynamics in a sub-Arctic peatland in northern Finland, Polar Research, 21, 49-62.

Heyer, J., U. Berger, I.L. Kuzin, and O.N. Yakovlev (2002), Methane emissions from different ecosystem structures of the subarctic tundra in Western Siberia during midsummer and during 
the thawing period, Tellus Series B-Chemical and Physical Meteorology, 54, 231-249.

Jackowicz-Korczynski, M., T.R. Christensen, K. Backstrand, P. Crill, T. Friborg, M.

Mastepanov, and L. Strom (2010), Annual cycle of methane emission from a subarctic peatland, Journal of Geophysical Research-Biogeosciences, 115.

Joabsson, A., and T.R. Christensen (2001), Methane emissions from wetlands and their relationship with vascular plants: an Arctic example, Global Change Biology, 7, 919-932.

King, J.Y., W.S. Reeburgh, and S.K. Regli (1998), Methane emission and transport by arctic sedges in Alaska: Results of a vegetation removal experiment, Journal of Geophysical Research-Atmospheres, 103, 29083-29092.

Kutzbach, L., D. Wagner, and E.M. Pfeiffer (2004), Effect of microrelief and vegetation on methane emission from wet polygonal tundra, Lena Delta, Northern Siberia, Biogeochemistry, 69, 341-362.

Lamb, E.G., S. Han, B.D. Lanoil, G.H.R. Henry, M.E. Brummell, S. Banerjee, and S.D. Siciliano (2011), A High Arctic soil ecosystem resists long-term environmental manipulations, Global Change Biology, 17, 3187-3194.

Lara, M.J., S. Villarreal, D.R. Johnson, R.D. Hollister, P.J. Webber, and C.E. Tweedie (2012), Estimated change in tundra ecosystem function near Barrow, Alaska between 1972 and 2010, Environmental Research Letters, 7.

Mastepanov, M., C. Sigsgaard, E.J. Dlugokencky, S. Houweling, L. Strom, M.P. Tamstorf, and T.R. Christensen (2008), Large tundra methane burst during onset of freezing, Nature, 456, 628-U58.

Merbold, L., W.L. Kutsch, C. Corradi, O. Kolle, C. Rebmann, P.C. Stoy, S.A. Zimov, and E.D. Schulze (2009), Artificial drainage and associated carbon fluxes (CO2/CH4) in a tundra ecosystem, Global Change Biology, 15, 2599-2614.

Moore, T.R., A. Heyes, and N.T. Roulet (1994), Methane emissions from wetlands, southern Hudson Bay lowland, Journal of Geophysical Research, 99, 1455-1467.

Moosavi, S.C., and P.M. Crill (1998), CH4 oxidation by tundra wetlands as measured by a selective inhibitor technique, Journal of Geophysical Research-Atmospheres, 103, 2909329106.

Morrissey, L.A., and G.P. Livingston (1992), Methane Emissions from Alaska Arctic Tundra an Assessment of Local Spatial Variability, Journal of Geophysical Research-Atmospheres, 97, 16661-16670.

Nakano, T., S. Kuniyoshi, and M. Fukuda (2000), Temporal variation in methane emission from tundra wetlands in a permafrost area, northeastern Siberia, Atmospheric Environment, 34, 1205-1213.

Oberbauer, S.F., G. Starr, and E.W. Pop (1998), Effects of extended growing season and soil warming on carbon dioxide and methane exchange of tussock tundra in Alaska, Journal of Geophysical Research-Atmospheres, 103, 29075-29082.

Oquist, M.G., and B.H. Svensson (2002), Vascular plants as regulators of methane emissions from a subarctic mire ecosystem, Journal of Geophysical Research-Atmospheres, 107.

Parmentier, F.J.W., J. van Huissteden, M.K. van der Molen, G. Schaepman-Strub, S.A. Karsanaev, T.C. Maximov, and A.J. Dolman (2011), Spatial and temporal dynamics in eddy covariance observations of methane fluxes at a tundra site in northeastern Siberia, Journal of Geophysical Research-Biogeosciences, 116.

Rhew, R.C., Y.A. Teh, and T. Abel (2007), Methyl halide and methane fluxes in the northern Alaskan coastal tundra, Journal of Geophysical Research-Biogeosciences, 112. 
Roulet, N.T., A. Jano, C.A. Kelly, L.F. Klinger, T.R. Moore, R. Protz, J.A. Ritter, and W.R. Rouse (1994), Role of the Hudson-Bay Lowland as a Source of Atmospheric Methane, Journal of Geophysical Research-Atmospheres, 99, 1439-1454.

Sachs, T., C. Wille, J. Boike, and L. Kutzbach (2008), Environmental controls on ecosystemscale CH4 emission from polygonal tundra in the Lena River Delta, Siberia, J. Geophys. Res., 113, G00A03.

Sachs, T., M. Giebels, J. Boike, and L. Kutzbach (2010), Environmental controls on CH4 emission from polygonal tundra on the microsite scale in the Lena river delta, Siberia,. Global Change Biology, 16, 3096-3110.

Schimel, J.P. (1995), Plant-Transport and Methane Production as Controls on Methane Flux from Arctic Wet Meadow Tundra, Biogeochemistry, 28, 183-200.

Sebacher, D.I., R.C. Harriss, K.B. Bartlett, S.M. Sebacher, and S.S. Grice (1986), Atmospheric methane sources: Alaskan tundra bogs, an alpine fen, and a subarctic boreal marsh. Tellus $38 B, 1-10$.

Stewart, K.J., M.E. Brummell, R.E. Farrell, and S.D. Siciliano (2012), N2O flux from plant-soil systems in polar deserts switch between sources and sinks under different light conditions, Soil Biology \& Biochemistry, 48, 69-77.

Strom, L., and T.R. Christensen (2007), Below ground carbon turnover and greenhouse gas exchanges in a sub-arctic wetland, Soil Biology \& Biochemistry, 39, 1689-1698.

Strom, L., T. Tagesson, M. Mastepanov, and T.R. Christensen (2012), Presence of Eriophorum scheuchzeri enhances substrate availability and methane emission in an Arctic wetland, Soil Biology \& Biochemistry, 45, 61-70.

Sturtevant, C.S., W.C. Oechel, D. Zona, Y. Kim, and C.E. Emerson (2012), Soil moisture control over autumn season methane flux, Arctic Coastal Plain of Alaska, Biogeosciences, 9, 14231440 .

Svensson, B.H., and T. Rosswall (1984), Insitu Methane Production from Acid Peat in PlantCommunities with Different Moisture Regimes in a Subarctic Mire, Oikos, 43, 341-350.

Svensson, B.H., T.R. Christensen, E. Johansson, and M. Oquist (1999), Interdecadal changes in $\mathrm{CO}(2)$ and $\mathrm{CH}(4)$ fluxes of a subarctic mire: Stordalen revisited after 20 years, Oikos, 85, 2230.

Tagesson, T., M. Molder, M. Mastepanov, C. Sigsgaard, M.P. Tamstorf, M. Lund, J.M. Falk, A. Lindroth, T.R. Christensen, and L. Strom (2012), Land-atmosphere exchange of methane from soil thawing to soil freezing in a high-Arctic wet tundra ecosystem, Global Change Biology, 18, 1928-1940.

Torn, M.S., and F.S. Chapin (1993), Environmental and Biotic Controls over Methane Flux from Arctic Tundra, Chemosphere, 26, 357-368.

van Huissteden, J., T.C. Maximov, and A.J. Dolman (2005), High methane flux from an arctic floodplain (Indigirka lowlands, eastern Siberia), Journal of Geophysical ResearchBiogeosciences, 110.

Verville, J.H., S.E. Hobbie, F.S. Chapin, and D.U. Hooper (1998), Response of tundra CH4 and $\mathrm{CO} 2$ flux to manipulation of temperature and vegetation, Biogeochemistry, 41, 215-235.

von Fischer, J.C., R.C. Rhew, G.M. Ames, B.K. Fosdick, and P.E. von Fischer (2010), Vegetation height and other controls of spatial variability in methane emissions from the Arctic coastal tundra at Barrow, Alaska, Journal of Geophysical Research-Biogeosciences, 115.

Whalen, S.C., and W.S. Reeburgh (1990), Consumption of Atmospheric Methane by Tundra 
Soils, Nature, 346, 160-162.

Wille, C., L. Kutzbach, T. Sachs, D. Wagner, and E.M. Pfeiffer (2008), Methane emission from Siberian arctic polygonal tundra: eddy covariance measurements and modeling, Global Change Biology, 14, 1395-1408.

Wilson, K.S., and E.R. Humphreys (2010), Carbon dioxide and methane fluxes from Arctic mudboils, Canadian Journal of Soil Science, 90, 441-449 